Review

\title{
Isocitrate Dehydrogenase Mutations in Glioma: Genetics, Biochemistry, and Clinical Indications
}

\author{
Yang Liu ${ }^{1}$, Fengchao Lang ${ }^{1}$, Fu-Ju Chou ${ }^{1}{ }^{(0)}$, Kareem A. Zaghloul ${ }^{2}$ and Chunzhang Yang ${ }^{1, *(D)}$ \\ 1 Neuro-Oncology Branch, Center for Cancer Research, National Cancer Institute, Bethesda, MD 20892, USA; \\ yang.liu5@nih.gov (Y.L.); fengchao.lang@nih.gov (F.L.); fu-ju.chou@nih.gov (F.-J.C.) \\ 2 Surgical Neurology Branch, National Institute of Neurological Disorders and Stroke, National Institutes of \\ Health, Bethesda, MD 20892, USA; kareem.zaghloul@nih.gov \\ * Correspondence: yangc2@nih.gov; Tel.: +1-240-760-7083
}

Received: 28 July 2020; Accepted: 17 August 2020; Published: 20 August 2020

\begin{abstract}
Mutations in isocitrate dehydrogenase $(I D H)$ are commonly observed in lower-grade glioma and secondary glioblastomas. IDH mutants confer a neomorphic enzyme activity that converts $\alpha$-ketoglutarate to an oncometabolite D-2-hydroxyglutarate, which impacts cellular epigenetics and metabolism. IDH mutation establishes distinctive patterns in metabolism, cancer biology, and the therapeutic sensitivity of glioma. Thus, a deeper understanding of the roles of IDH mutations is of great value to improve the therapeutic efficacy of glioma and other malignancies that share similar genetic characteristics. In this review, we focused on the genetics, biochemistry, and clinical impacts of $I D H$ mutations in glioma.
\end{abstract}

Keywords: $I D H$ mutation; glioma; cancer; therapy resistance

\section{Introduction}

In 2008, compelling research showed that mutations in isocitrate dehydrogenase (IDH1 and $I D H 2)$ are frequently identified in the World Health Organization (WHO) grade II/III gliomas and secondary glioblastomas (GBMs). In contrast, these mutations are rare in primary GBM patients [1]. In 2009, Yan et al. [2] showed that IDH1 and IDH2 mutations frequently occur in WHO grade II/III astrocytomas and oligodendrogliomas. Besides gliomas, IDH mutations also occur in other non-central nervous system (CNS) malignancies, including acute myeloid leukemia (AML) [3,4], intrahepatic cholangiocarcinoma [5,6], chondrosarcoma [7], and melanoma [8,9]. The mutations are confined to a single arginine residue $\left(\mathrm{Arg}^{132}\right)$ in $I D H 1$ or two arginine residues ( $\operatorname{Arg}^{172}$ and $\left.\mathrm{Arg}^{140}\right)$ in IDH2 [10,11]. The mutations commonly cause amino acid substitutions, which localize at the active sites of the enzymes and alter the catalytic functions of IDH enzymes. In contrast to wild-type IDH, which transforms isocitrate into $\alpha$-ketoglutarate $(\alpha-K G)$, the mutated IDHs convert $\alpha-K G$ into D-2-hydroxyglutarate (D-2-HG) [12]. The altered catalytic activity that occurs because of cancer-associated IDH mutations was later termed "neomorphic activity". The overproduction of the oncometabolite D-2-HG leads to widespread physiological consequences, including profound effects on cellular metabolism [13,14], epigenetic shift [15-18], genomic instability [19-23], and redox homeostasis [24-29]. IDH mutations are considered founder events for oncogenesis, through which an ancestor glial cell commits to malignant transformation. On the other hand, the mutant IDH enzyme brings about substantial changes in cancer biology, thereby establishing novel therapeutic vulnerabilities that are not commonly identified in other neoplasms. In the present review, we provide an overview of the current knowledge regarding IDH mutations in glioma and discuss the distinctive features in terms of genetic, biochemical, and clinical indications in detail. 


\section{Genetics of Glioma}

\subsection{The Prevalence of IDH Mutation in Glioma (Lower-Grade Glioma and GBM)}

IDH mutations occur in approximately $80 \%$ of all WHO grade II/III gliomas (also known as lower-grade glioma (LGG)) and secondary GBMs [2,30]. In contrast, IDH mutations only account for less than $5 \%$ of clinical cases of GBM, suggesting that LGG and GBM are minimally overlapping disease subtypes (Figure 1A). The aggregate data from many preclinical and clinical studies have shown that IDH mutations alone are insufficient for malignant transformation [31,32]. IDH mutations occur at the early stage of gliomagenesis, and often acquire secondary genetic abnormalities such as mutations in tumor protein 53 (TP53), loss of ATP-dependent helicase ATRX, X-linked helicase II (ATRX), or chromosomal region $1 \mathrm{p} / 19 \mathrm{q}$ co-deletion. These alterations correlate to the histological classification of the disease. For example, IDH mutant diffuse astrocytomas frequently harbor TP53 mutations and loss of ATRX [33-35], while these changes are less likely to be observed in most IDH mutant oligodendrogliomas $[35,36]$. In contrast, most histologically confirmed IDH mutant oligodendrogliomas harbor $1 \mathrm{p} / 19 \mathrm{q}$ co-deletion [37-41]. Interestingly, a majority of glioma patients with IDH mutation and $1 \mathrm{p} / 19 \mathrm{q}$ co-deletion also acquire mutations in the promoter regions of the telomerase reverse transcriptase (TERT) [36,42]. Moreover, mutations of homolog of Drosophila capicua transcriptional repressor (CIC) and far upstream element binding protein 1 (FUBP1) occur frequently in tumors with $1 \mathrm{p} / 19 \mathrm{q}$ loss in oligodendrogliomas [37,41]. In contrast, these secondary genetic abnormalities are rare in IDH wild-type gliomas, while EGFR amplification appears to occur more frequently compared with IDH mutant gliomas (Figure 1B) [1,43]. Recently, an exome sequencing screening in EGFR-mutated gliomas identified multiple cooperating partner genes that are associated with EGFR driving gliomagenesis, including Cdkn2a, Nf1, Spred1, and Nav3. However, IDH mutations are not associated with EGFR, suggesting no cooperation between these two genes during gliomagenesis [44]. A combination of these genetic signatures and histology provides extra information for accurate glioma subtype classification, and aids in differential diagnosis. With the high prevalence and distinct clinical phenotype of $I D H$-mutated glioma, the WHO updated the classification of CNS malignancies, with an emphasis on the consideration of IDH mutations as a marker for genetic diagnosis [45].
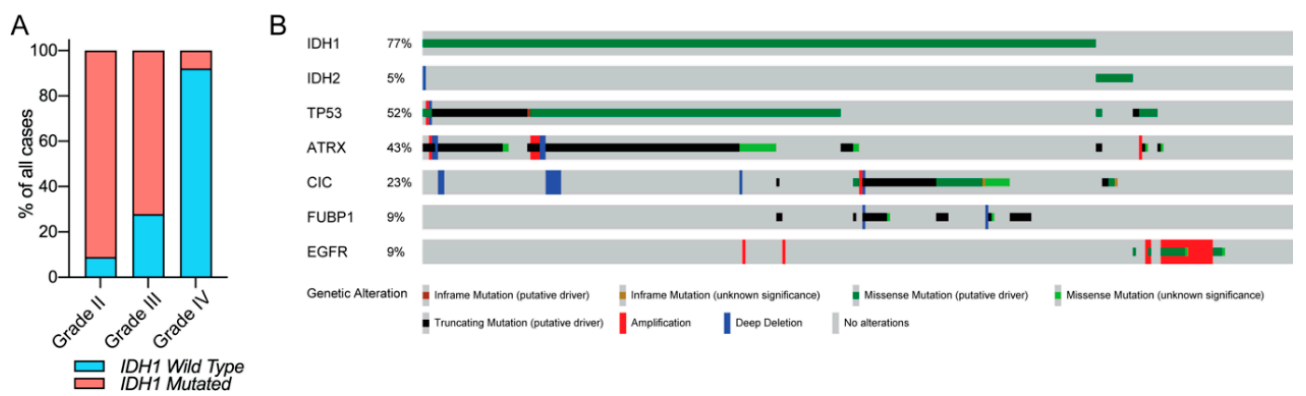

Figure 1. Isocitrate dehydrogenase (IDH) mutation in glioma. (A) The prevalence of the IDH1 mutation in glioma based on the pathologic grade. (B) Common genetic alterations in lower-grade glioma (LGG). IDH1/2 missense mutations are frequently observed in LGG. IDH-mutated LGG frequently harbors missense or truncating mutations in TP53, ATRX, capicua transcriptional repressor (CIC), and far upstream element binding protein 1 (FUBP1). EGFR gene amplifications and/or missense mutations are observed frequently in IDH wild-type gliomas, but rarely so in $I D H$-mutated cases. The data are visualized through cBioPortal $[46,47]$.

\subsection{Hypermethylation Phenotype in a Subset of IDH-Mutated Gliomas}

Several clinical studies have shown that IDH mutations correlate significantly with both global DNA hypermethylation and histone methylation [18,48,49]. Through an analysis of a dataset from The Cancer Genome Atlas (TCGA) containing 272 GBM cases, Noushmehr et al. [48] reported that a subset of gliomas exhibits extensive DNA methylation throughout the genome. This was later 
termed glioma-CpG Island Methylator Phenotype (G-CIMP). Furthermore, the researchers validated G-CIMP in non-TCGA GBMs and LGGs, and revealed a strong association between G-CIMP and IDH1 mutations. A similar study conducted by Christensen et al. [49] showed vastly different methylation patterns across glioma tumor histological subtypes. The IDH mutations were strongly associated with a substantial increase in hypermethylation loci, despite their histological diversity. Through in vitro studies, Turcan et al. [18,50] demonstrated that the acquisition of IDH mutation is sufficient to establish the genome-wide hypermethylation of CpG islands, which recapitulate the G-CIMP in patients. These findings indicate that IDH mutations play a critical role in epigenetic modulation in gliomas. The CpG island methylator phenotype could be lost through the progression of IDH-mutated glioma, which mimics IDH wild-type stem cell-like GBM, and generally predisposes patients to a poor clinical outcome [51].

\section{Biochemistry of $I D H$}

\subsection{Wild-Type IDH}

In 1939, Adler et al. [52] first isolated IDH from animal tissue. They demonstrated that this enzyme catalyzes the transformation of isocitrate to $\alpha$-keto- $\beta$-carboxyglutaric acid, which spontaneously yields $\alpha$-ketoglutaric acid and $\mathrm{CO}_{2}$.

$$
\text { Isocitrate }+\mathrm{NAD}(P)^{+} \rightleftharpoons \alpha-\mathrm{KG}+\mathrm{CO}_{2}+\mathrm{NAD}(P) \mathrm{H}+\mathrm{H}^{+}
$$

Since IDH was discovered, investigations through the decades have revealed that it plays an essential role in numerous pivotal biological processes, including the Krebs cycle, glutamine metabolism, lipid synthesis, and redox homeostasis [53]. Human cells express three isoforms of IDH. IDH1 is localized in the cytoplasm and peroxisomes, whereas IDH2 and IDH3 are found in the mitochondrial matrix. Despite the differences in their localization, IDH1 and IDH2 are both heterodimers and exhibit a high similarity in gene sequences (Figure 2A). IDH1 and IDH2 catalyze identical, reversible reactions, as follows: decarboxylation of isocitrate to form $\alpha-K G$, while reducing $\mathrm{NADP}^{+}$, as a cofactor, to form NADPH (Figure 2B). IDH3 is a holoenzyme that comprises two $\alpha_{2} \beta \gamma$ heterotetramers. Although IDH3 comprises a complex with more subunits, it catalyzes a similar reaction to decarboxylate isocitrate, and uses $\mathrm{NAD}^{+}$as a cofactor [54]. As cancer-associated mutations occur predominantly in IDH1, we mainly focus on IDH1 mutants and their impact on cancer biology.

A

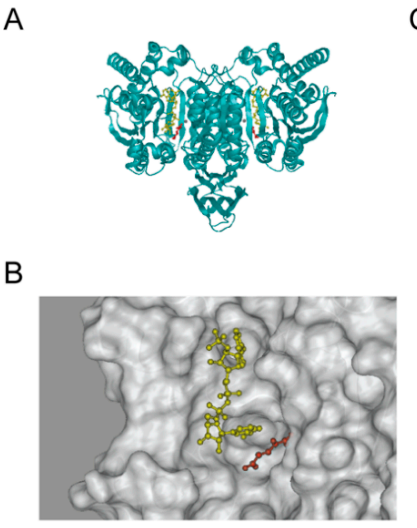

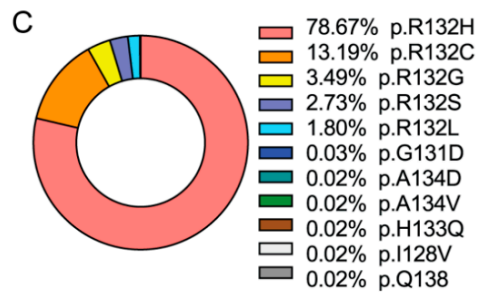

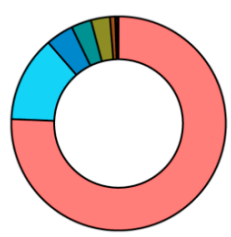

$75.65 \%$ Glioma

$4.17 \%$ Carcinoma

$3.04 \%$ Chondrosarcoma

$0.29 \%$ Haemangioma

$12.99 \%$ Haematopoietic neoplasm

$0.79 \%$ Malignant melanoma

$0.11 \%$ Primitive neuroectodermal tumour-medulloblastoma

$0.10 \%$ Lymphoid neoplasm

Figure 2. Cancer-associated-IDH1 mutation. (A) Ribbon diagrams of the IDH1 structure in Homo sapiens. NADP is highlighted in yellow. $\alpha$-Ketoglutarate $(\alpha-K G)$ is highlighted in red. The structure is visualized based on the known crystallography $4 \mathrm{KZO}$ [55]. (B) The structure of the catalytic center of the IDH1 enzyme. NADPH is highlighted in yellow. $\alpha-K G$ is highlighted in red. The structure is visualized based on the known crystallography $4 \mathrm{KZO}$. (C). The frequency of IDH1 somatic mutations (upper panel) and IDH1 mutations in human malignancies (lower panel). Percentages were calculated from the Catalogue of Somatic Mutations in Cancer (COSMIC) database [56]. 


\subsection{IDH Neomorphic Activity and D-2-HG}

Cancer-associated IDH mutations are mostly missense mutations, which lead to amino acid substitutions at specific arginine residues in the core active sites. In IDH1, the amino acid substitution commonly affects $\operatorname{Arg}^{132}$, whereas in IDH2, the mutations cluster in $\operatorname{Arg}^{140}$ or $\operatorname{Arg}^{172}$. The $\mathrm{R} 132 \mathrm{H}$ and R132C variants of the IDH1 mutations are the most observed somatic changes in human malignancies, and are identified in $91.86 \%$ of all IDH1-mutated cancers (Figure 2C). The IDH1 R132H variant is predominantly found in gliomas, hematopoietic cancers, carcinoma, and chondrosarcoma (Figure 2C). The amino acid substitution from $\operatorname{Arg}^{172}$ to lysine $(\mathrm{K})$ is the most common variant present in IDH2-mutated glioma [40]. IDH2 $\mathrm{Arg}^{132}$ and IDH2 $\mathrm{Arg}^{172}$ are highly conserved in the catalytic active sites, and play critical roles in the recognition of their substrate isocitrate [57]. It has been reported that IDH mutations lead to impaired NADPH production and a decreased affinity for isocitrate, which may suggest that mutations yield a dominant negative inhibition of the enzymes [2]. However, several subsequent investigations, particularly the pioneering work by Dang et al. [58], have reported that cancer-associated IDH1 mutations led to an alteration in the substrate preference of the enzyme, such that the mutant enzyme exhibits a higher affinity for $\alpha-K G$. In addition, IDH1 mutation results in a neomorphic activity that converts $\alpha-K G$ to D-2-HG, in an NADPH-dependent manner. Similarly, IDH2 mutants also showed a neomorphic activity by producing D-2-HG in glioma and leukemia [11,59].

$$
\alpha-K G+N A D(P) H \rightarrow D-2-H G+N A D(P)^{+}
$$

\subsection{Distinctive Biological Patterns of IDH-Mutated Glioma}

The neomorphic activity of IDH mutants results in the production of a large quantity of D-2-HG. The accumulation of D-2-HG impacts cancer biology by affecting $\alpha$-KG-dependent enzymes, which establishes a distinctive phenotype in the $I D H$-mutated glioma $[15,16]$. D-2-HG influences a wide spectrum of molecular pathways, including those of epigenetic modulation, DNA repair, metabolism, redox balance, and the immune system. Investigations on these pathways provide a deep understanding of the IDH mutations in glioma biology, and justifications for targeting these pathways in the treatment of IDH mutant gliomas.

\subsection{Histones and DNA Demethylases}

The chemical structure of D-2-HG ( $\alpha$-hydroxyglutaric acid) is similar to that of $\alpha$-KG (2-oxoglutaric acid). The accumulation of D-2-HG likely affects the oxidoreductases that use $\alpha-K G$ as a cofactor. D-2-HG has been shown to inhibit multiple histone demethylases, including KDM7A (demethylate H3K9me2 and H3K27me2) [15], KDM4A/B (demethylate H3K9) [60], and H3K36 demethylases [61]. The pioneering research conducted by $\mathrm{Xu}$ et al. [15] demonstrated that D-2-HG competitively inhibits $\alpha$-KG-dependent histone demethylases. Molecular modeling revealed that D-2-HG occupies the $\alpha$-KG binding site and hampers the demethylation reaction of histones. Similarly, D-2-HG competitively inhibits ten-eleven translocation methylcytosine dioxygenase 1 and 2 (TET1 and TET2). TET catalyzes the demethylation reactions involving the conversion of 5-methylcytosine (5-mC) to 5-hydroxymethylcytosine (5-hmC), 5-hmC to 5-formylcytosine (5-fC), and 5-fC to 5-carboxylcytosine (5-caC). The presence of D-2-HG limits the efficacy of cytosine demethylation, which results in the accumulation of 5-mC throughout the genome $[15,62]$. These findings later confirmed that the acquisition of IDH1 mutants or high amounts of D-2-HG is sufficient to induce the hypermethylation phenotype identified among patients with IDH-mutated gliomas [18]. Epigenetic reprogramming may lead to the oncogenesis of glioma and other malignancies. For example, Flavahan et al. [63] reported that $I D H$ mutant gliomas exhibit hypermethylation at cohesin and CCCTC binding factor (CTCF)-binding sites, which compromises the binding of this important insulator protein. CTCF plays a critical role in maintaining the insulation between topological domains and preventing aberrant gene activation. Loss of CTCF binding leads to the constitutive expression of the receptor tyrosine kinase gene PDGFRA and promotes gliomagenesis. In addition, the D-2-HG-associated hypermethylation 
phenotype impedes cellular differentiation by inhibiting lysine-specific demethylase 4C (KDM4C), which may assist in the maintenance of stemness and gliomagenesis [17].

\subsection{DNA Repair Enzymes}

DNA repair is an evolutionarily conserved cellular function, which is commonly exploited by cancer cells against genotoxic therapies, such as radio- and chemo-therapy [64]. DNA repair involves a spectrum of highly sophisticated molecular mechanisms, and employs multiple DNA modification enzymes $[65,66]$. A growing body of evidence suggests that D-2-HG affects multiple DNA repair pathways. For example, Wang et al. [19] reported that $I D H$-mutant-induced D-2-HG inhibits the $\alpha$-KG-dependent alkB homolog (ALKBH) DNA repair enzymes, which sensitize IDH mutant cancers to DNA alkylating agents. In addition, Ohba et al. [67] reported that mutant IDH1 drives a unique set of transformative events, resulting in increased RAD51-mediated homologous recombination (HR). Moreover, Inoue et al. [20] reported that mutant IDH1 downregulates the DNA damage sensor ataxia-telangiectasia-mutated (ATM) signaling pathway by altering histone methylation, leading to sensitivity to DNA damaging agents. Another study conducted by Núñez et al. [68] showed that in the context of ATRX loss, IDH mutant cancers enhance DNA damage response via the up-regulation of the ATM pathway, suggesting that ATRX deficiency in diffusive astrocytoma may affect DNA repair pathways and sensitivity to therapy. Finally, us and several groups have reported that the poly (ADP-ribose) polymerase-1 (PARP1)-associated DNA repair pathway is compromised extensively in mutant cells because of decreased $\mathrm{NAD}^{+}$availability. Combinations including PARP inhibitors sensitize IDH mutant cancers to chemotherapy and radiotherapy $[21,22,69]$. The seminal research conducted by Sulkowski et al. $[23,70]$ revealed that D-2-HG compromises HR DNA repair by influencing histone methylation and local chromatin signaling. With the substantial expansion in knowledge regarding the D-2-HG-suppressed DNA repair pathway, it is possible to improve the current standard of care for glioma, through the sensitization of cancer cells with molecular targeting approaches against remnant DNA repair pathways.

\subsection{Metabolic Enzymes}

The neomorphic activity of mutant $I D H$ completely alters the metabolic flux in the Krebs cycle, and therefore establishes a distinctive pattern in cancer metabolism. Grassian et al. [71] reported that cells expressing mutant IDH1 show increased oxidative tricarboxylic acid metabolism, along with suppressed reductive glutamine metabolism under hypoxic conditions. Reitman et al. [72] profiled more than 200 metabolites in human oligodendroglioma cells in order to investigate metabolic reprogramming by the IDH1 mutant enzyme. The researchers discovered that glutamate levels were reduced in cells with $I D H$ mutants. The reduction in glutamate levels might indicate that $\alpha-K G$ is replenished by glutaminolysis. Ohka et al. [73] provided additional insights into glutamine catabolism in IDH-mutated cells. The researchers reported that glutaminolysis is activated in IDH mutant cells. Furthermore, several studies have shown that the inhibition of glutaminases suppresses the growth of IDH mutant cancers, which indicates that reduced glutamate and increased dependence on glutaminolysis are key features of IDH mutant cancers [29,74].

\subsection{Anti-Oxidative Pathways}

The cellular redox status is maintained by the balance of NADPH/NAPD ${ }^{+}$. The neomorphic activity of the IDH mutant enzyme utilizes NADPH as a cofactor, and therefore exhausts the availability of the reductive equivalent for biosynthetic reactions [24-26]. Our previous studies have shown that the acquisition of IDH mutants is associated with elevated levels of reactive oxygen species (ROS), suggesting a distinctive pattern in redox homeostasis in malignancies with IDH mutants. The increased ROS burden was considered harmful to cells, which might lead to catastrophic oxidative damage. Moreover, we discovered that IDH mutant cells mobilize multiple anti-oxidative pathways to maintain 
the fragile redox homeostasis. NRF2-governed anti-oxidative pathways, such as that of de novo glutathione synthesis, play a pivotal role in the manifestation of $I D H$-mutated glioma $[25,27,28]$.

\section{Clinical Indications Involving the Discovery of IDH-Mutated Glioma}

\subsection{Clinical Classification of Gliomas}

The 2016 WHO classification of CNS tumors has suggested the use of integrated phenotypic and genotypic characterization, which provides an increased level of objectivity [75]. In particular, $I D H$ mutations have become some of the most important parameters in the differential diagnosis of gliomas. For example, diffuse astrocytomas often harbor IDH mutations, followed by other mutations such as TP53 and ATRX. Oligodendrogliomas are characterized by IDH mutations along with $1 \mathrm{p} / 19 \mathrm{q}$ co-deletion (potentially along with CIC and FUBP1 mutations). The IDH mutation status is also useful for the differential diagnosis of primary and secondary GBMs [75-77]. Moreover, as IDH mutations frequently induce genome-wide DNA and histone hypermethylation, the introduction of methylation profiling allows for further improving the accuracy of glioma classification. Recently, Jaunmuktane et al. [78] demonstrated a diagnostic algorithm that integrated histology, molecular signature, and methylation array, and improved the diagnostic approach. Thus, the IDH mutation status is of great value in glioma classification and the selection of appropriate therapeutic strategies.

\subsection{Radiology-D-2-HG Imaging}

D-2-HG is a novel metabolite that accumulates in extremely high levels in glioma cells, but is absent in normal brain cells. The drastic contrast in cellular D-2-HG levels suggests that this oncometabolite could be an ideal biomarker for clinical monitoring and diagnosis among patients with IDH-mutated cancers [79]. Several hallmark studies have developed noninvasive radiologic methods for the detection of D-2-HG, such as magnetic resonance spectroscopy (MRS). In IDH mutant gliomas, D-2-HG accumulates to sufficient levels as a brain metabolite, which renders its visibility on MRS. These levels are 2-3 orders of magnitude higher than those found in the adjacent normal brain tissues [79]. Andronesi et al. [80] reported that D-2-HG was detected unambiguously in mutant IDH1 glioma in vivo using 2D correlation spectroscopy (COSY) and J-difference spectroscopy. Several other studies have also reported that D-2-HG is detected among glioma patients or in animal models using the short echo times (TEs) method [81-84]. On the other hand, D-2-HG levels were detected in glioma patients using long TE methods and J-difference spectroscopy with $100 \%$ sensitivity $[85,86]$. The application of long TE methods in D-2-HG detection has been confirmed in several subsequent reports, with increased sensitivity and specificity $[87,88]$. Overall, the noninvasive detection of D-2-HG has been proven to be a valuable diagnostic and prognostic biomarker. D-2-HG imaging provides a useful approach to the clinical management of patients with $I D H$-mutated glioma. Fluctuations in D-2-HG levels may provide crucial longitudinal data for the determination of disease progression and therapy response [79].

\subsection{Disease Outcomes-Prolonged Survival}

In 2008, Parsons et al. [1] first reported that mutations in IDH1 occurred in most patients with secondary GBM, and were associated with better overall survival (OS). Similar trends were reported in numerous studies using various datasets [42,89-93]. For example, using a large clinical dataset, Yan et al. [2] reported that GBM patients harboring IDH1 or IDH2 mutations tend to have a prolonged median OS compared with patients with IDH wild-type GBM. Similar findings were also observed among patients with anaplastic astrocytoma. The median OS was 65 months for patients with $I D H$ mutant disease, compared with 20 months for those with IDH wild-type disease. Moreover, the progression-free survival (PFS) was also improved among GBM patients with IDH mutations compared with their counterparts [89]. Secondary genetic alterations, such as TP53/ATRX mutations 
and $1 \mathrm{p} / 19 \mathrm{q}$ co-deletion, predispose patients with $I D H$-mutated gliomas to slightly different OS and disease-free survival (DFS; Figure 3A,B). Several studies have reported that IDH mutations are associated with younger age at diagnosis and limited genome alterations among patients with WHO grade II/III gliomas and GBMs, which may bias the disease outcome (Figure 3C,D) [1,2,94,95]. However, in a multivariate analysis, Sanson et al. [89] showed that the IDH mutation status is an independent predictor of favorable outcomes among glioma patients.

A

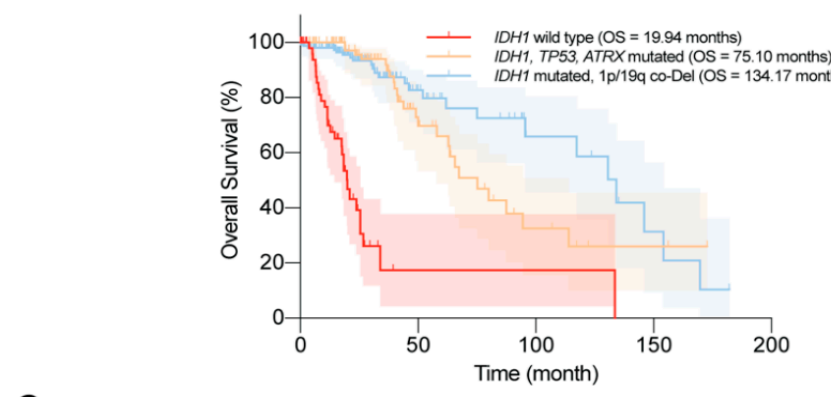

C

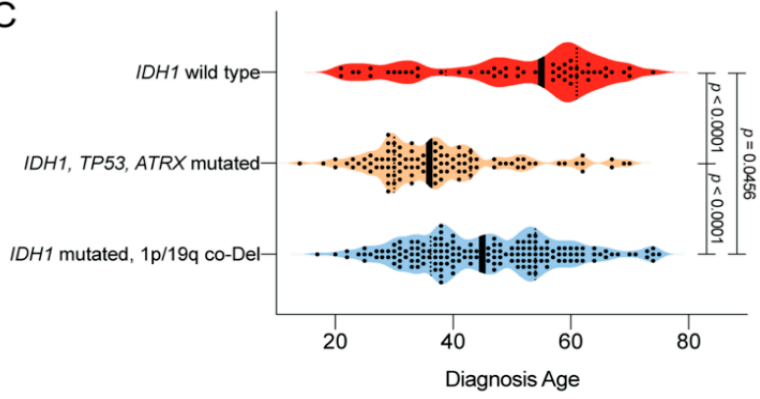

B

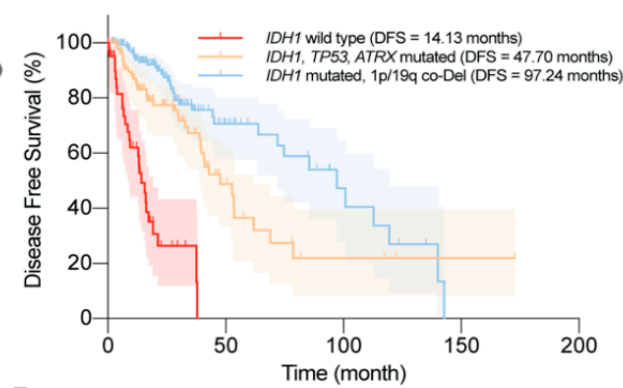

D

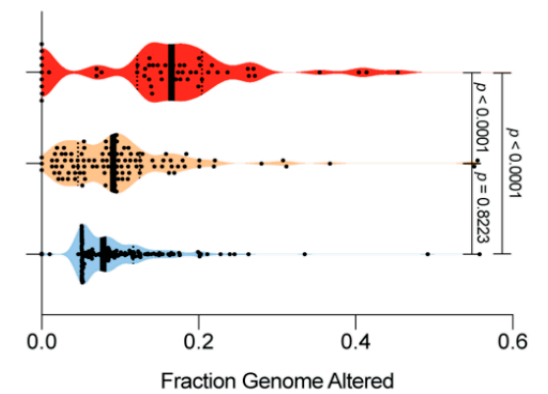

Figure 3. Clinical features of the World Health Organization (WHO) grade II/III IDH-mutated glioma. (A) Overall survival (OS) of glioma patients according to IDH1 status. IDH1 mutations are associated with prolonged OS. (B) Disease-free survival (DFS) of glioma patients according to IDH1 status. IDH1 mutations are associated with prolonged DFS. (C) Age at diagnosis among glioma patients according to IDH1 status. IDH1 mutations are associated with a younger age at diagnosis. (D) The distribution of genome alterations in glioma according to IDH1 status. IDH1 mutations are associated with fewer genome alterations. The data are visualized in cBioPortal $[46,47]$.

\subsection{Complications—Epilepsy and Secondary GBM}

Epileptic seizure is one of the most common complications among patients with glioma, particularly those with LGGs (up to 90\%) [96-99]. Severe seizures impair the quality of life and neurocognition function among glioma patients [100]. Considering the high incidence of IDH mutations in LGG, it is likely that the epileptic changes are relevant to the unique patterns in the tumor microenvironment, which is associated with IDH mutants. Numerous studies have indicated that mutations in IDH are associated with a high prevalence of epilepsy [101-105]. For example, Chen et al. [104] showed that IDH mutations are independently correlated with seizures, regardless of WHO grade. A recent study suggested that D-2-HG overproduction in the tumor microenvironment plays a major role in glioma-related epilepsy. D-2-HG is structurally similar to glutamate, which is the predominant excitatory neurotransmitter in the CNS. Thus, D-2-HG may act as an analog of glutamate, which leads to the abnormal firing of neurons through activating N-Methyl-d-aspartic acid (NMDA) receptors, and hence epileptic changes. Treating cultured rat cortical neurons with exogenous D-2-HG resulted in an elevated firing rate [104]. By mimicking the activity of glutamate, the increased level of D-2-HG mediates the abnormal neuronal activity and leads to glioma-related epilepsy $[80,106,107]$. However, three millimolar D-2-HG induced an elevated burst frequency in the neuronal network in vitro [104], whereas this dose is over 30 times higher than the glutamate concentration for excitotoxicity [108]. More effort is urged in order to elucidate the detailed molecular 
mechanism of the epileptic changes in IDH-mutated glioma. Because of the association between IDH mutations and seizures, therapies that target mutant $I D H$, such as mutant $I D H$ inhibitors, could diminish D-2-HG production and potentially reduce epileptic seizures [109].

\subsection{Sensitivity to Radiotherapy and Chemotherapy}

Clinical data have shown that $I D H$ mutant gliomas tend to exhibit a better disease outcome compared with wild-type IDH tumors. Several studies have explained that the favorable prognosis of IDH mutant gliomas is due to their increased sensitivity to radiotherapy and chemotherapy $[110,111]$. IDH mutant gliomas likely harbor defects in multiple DNA repair pathways, which render them vulnerable to radiotherapy- or chemotherapy-induced DNA damage [19,22]. These findings indicate that $I D H$ mutation could serve as an important predictive factor for treatment response among glioma patients. For example, Houillier et al. [111] reported that IDH1 mutation is an independent predictor of temozolomide response among LGG patients. IDH1 mutations combined with 1p/19q co-deletion further improved the treatment response. Hartman et al. [112] also reported that IDH1 status is an important predictor of disease-free survival (DFS) and OS among patients undergoing adjuvant therapy. In another study conducted by van de Bent et al. [113], no correlation was found between IDH1 mutations and disease outcome in response to procarbazine (Matulane), lomustine (CCNU), and vincristine (Oncovin) chemotherapy.

\section{Novel Molecular Targeting for IDH-Mutated Glioma}

\subsection{IDH Mutant Inhibitors}

Because of the critical roles played by IDH mutations in the malignant transformation of glioma, targeting the neomorphic activity of IDH mutants has been heavily proposed as a direct therapeutic approach. In the past decade, several attempts have been made to develop small molecular compounds that directly inhibit mutant $I D H$ enzymes. In 2012, the first-in-class mutant IDH inhibitor was discovered, which showed a specific and potent inhibitory effect on D-2-HG production in IDH mutant U87 cells and xenograft models [114]. Later, Rohle et al. [109] reported a novel synthetic inhibitor of IDH mutant, AGI-5198, which blocked D-2-HG production and subsequently reversed the malignant transformation effect of IDH mutations. Besides glioma, the inhibition of mutant IDH promotes differentiation in leukemia harboring $I D H$ mutations [6]. With the promising findings regarding AGI-5198, second-generation mutant IDH inhibitors are under development and are undergoing evaluation in clinical studies. For example, ivosidenib (AG-120) and vorasidenib (AG-881) have been tested in AML and glioma with IDH mutations [115-118]. In a recent phase I clinical study with ivosidenib in IDH1-mutated advanced glioma conducted by Mellinghoff et al. [119], the mutant $I D H$ inhibitor appeared to be well-tolerated throughout the experiment, which paved the way for subsequent clinical studies to evaluate its therapeutic efficacy. Although the IDH mutant enzyme inhibitors suppress malignancy, several studies have suggested that this inhibitor reduces D-2-HG production and relieves the burden on the DNA repair pathway, resulting in chemoresistance to other therapies, such as PARP inhibitors [23,120]. More effort is urged to explore the strategy of combining IDH mutant inhibitors with other glioma therapies in order to improve the clinical outcome.

\subsection{Targeting Hypermethylation Phenotype}

Genome-wide DNA and histone hypermethylation is a unique signature in IDH-mutated glioma, which is closely related to gliomagenesis by promoting oncogene expression and inhibiting tumor suppressors [63]. This rectification of the epigenetic shift could be a reasonable strategy for halting D-2-HG-driven oncogenesis and the malignant phenotype. DNA-demethylating agents such as 5-azacytidine or 5-aza-2'-deoxycytidine (decitabine) irreversibly bind to DNA methyltransferases (DNMTs) and inhibit the process of DNA methylation. The D-2-HG-induced hypermethylation phenotype was reversed by demethylating compounds, and cell proliferation was suppressed in vitro 
and in vivo [121-123]. Several clinical trials are evaluating the therapeutic effects of 5-azacytidine among patients with recurrent gliomas with IDH mutations (NCT03666559 and NCT03684811). On the other hand, inhibitors targeting histone methyltransferases inhibitors are also being investigated for $I D H$-mutated gliomas, as an alternative strategy to rectify the D-2-HG-associated hypermethylation phenotype. It is reported that H3K9 methyltransferase G9a is correlated to the development and progression of glioma, and its inhibitor BIX-01294 showed repressive effects on gliomas cells [124].

\subsection{Targeting DNA Repair Pathways}

As previously mentioned, IDH mutant gliomas exhibit defects in multiple DNA repair pathways. High levels of D-2-HG inhibit the activity of DNA oxidative demethylases, such as AlkB homolog 2/3 (ALKBH2/3) [19]. Several seminal studies have also indicated that D-2-HG compromises HR DNA repair, establishing a "BRCAness" in this type of malignancy [23,125]. In addition, IDH mutation-associated G-CIMP resulted in the methylation of the promoter region of O-6-methylguanine-DNA methyltransferase (MGMT), which reduced MGMT expression and led to increased sensitivity to alkylating agents $[90,126,127]$. Our recent study indicated that IDH mutations led to defects in NAD metabolism, which compromised PARP-associated HR, as PARP repairs DNA damage in an $\mathrm{NAD}^{+}$dependent manner $[22,69]$. With the identification of the DNA repair deficiency in $I D H$-mutated glioma, numerous studies have attempted to evaluate DNA repair inhibitors, which may serve as a potential sensitization strategy. Several other groups and as well as ours reported that a combination of PARP inhibitors, such as olaparib, with temozolomide or radiotherapy, led to synergistic lethality in IDH mutant glioma cells [21-23]. Several phase I/II clinical trials are currently recruiting patients to investigate the therapeutic effect of the PARP inhibitors, pamiparib (BGB-290) or olaparib, combined with temozolomide in IDH mutant gliomas (NCT03914742, NCT03749187, and NCT03212274).

\subsection{Targeting Anti-Oxidative Pathways}

Redox homeostasis has been reported to be greatly impacted by IDH mutations, highlighted by profoundly elevated levels of oxidative stress [24-28]. As a result, ROS scavenging pathways are widely mobilized in the context of IDH mutation, so as to maintain cellular metabolism, thereby supporting cellular growth and survival. These findings suggest that the antioxidant pathway plays an essential role in $I D H$-mutated glioma. Targeting anti-oxidative pathways may be more effective in glioma with IDH mutations. Our recent study showed that NRF2-governed anti-oxidative pathways, such as that regarding de novo glutathione synthesis, were widespread in $I D H$ mutant gliomas. The blockade of NRF2 using natural compound inhibitors, brusatol, or triptolide significantly increased oxidative damage and subsequently suppressed the growth of $I D H$ mutant xenografts with prolonged OS $[25,27,28,128]$. The concept of targeting redox homeostasis in IDH mutant cancers has shown a potential therapeutic value. The development of pharmacological grade NRF2 inhibitors is needed urgently for potential clinical translation.

\subsection{Targeting Metabolic Reprogramming}

D-2-HG is a metabolite that is absent in normal cells. The production of large quantities of D-2-HG inevitably depletes a substantial amount of carbohydrate from the Krebs cycle. Several hallmark studies have demonstrated the presence of depleted metabolic pathways in $\mathrm{IDH}$-mutated cells. For example, glutamate metabolism is greatly altered in $I D H$ mutant glioma, as mentioned before. The glutamate level is significantly lower in IDH mutant cancers, which leads to an increased dependence on glutaminolysis to compensate for the metabolism $[29,74,129,130]$. Several studies have reported that a blockade of glutaminase activity results in the suppression of IDH mutant glioma and AML. Seltzer et al. and Emadi et al. [74,129] reported that bis-2-(5-phenylacetamido-1,2,4-thiadiazol-2-yl) ethyl sulfide (BPTES), an inhibitor of glutaminase, selectively suppresses tumor growth in IDH mutant glioma and AML by targeting the fragile glutamine metabolism. Another glutaminase inhibitor (CB-839) was also 
reported to induce selective radio-sensitivity in $I D H$ mutant cancers [29] and terminal differentiation in IDH mutant AML [130]. An ongoing phase I clinical trial is investigating the side effects and the best dose of CB-839, in combination with radiation therapy and temozolomide, for treating IDH-mutated diffuse or anaplastic astrocytoma (NCT03528642). In addition, IDH mutations lead to the depletion of $\mathrm{NAD}^{+}$because of the increased methylation of the promoter region of NAPRT1, the rate-limiting enzyme in $\mathrm{NAD}^{+}$biosynthesis, and suppression of the expression of NAPRT1. This renders the IDH mutant glioma vulnerable to inhibition through the nicotinamide phosphoribosyltransferase (NAMPT) catalyzed $\mathrm{NAD}^{+}$salvage pathway [131]. Moreover, Tateishi et al. [132] showed that NAMPT inhibitors further sensitized IDH mutant cancer cells to alkylating agents, such as temozolomide, as PARP activation consumes $\mathrm{NAD}^{+}$during the base excision repair of chemotherapy-induced DNA damage. With the substantially exhausted metabolic pathways, distinctive metabolic vulnerabilities are established in IDH-mutated malignancies. Effectively targeting these metabolic pathways may induce selective cytotoxicity to cancer cells, but a lesser extent than that occurs in normal somatic cells with an intact metabolic network.

\subsection{Immunotherapies}

The accumulated pieces of evidence have indicated that IDH mutant cancers exhibit an immunosuppressive tumor microenvironment [133,134]. Bunse et al. [133] reported that the D-2-HG produced by mutant IDH is taken up by $\mathrm{T}$ cells and suppresses $\mathrm{T}$ cell activity. Moreover, Kohanbash et al. [134] reported that IDH mutations inhibit STAT1 expression, and subsequently attenuate $\mathrm{CD}^{+} \mathrm{T}$ cell accumulation in gliomas. This evidence indicates that effective immunotherapy in $I D H$ mutant cancers could be challenging. However, numerous studies have suggested different approaches to overcoming IDH mutant related immunosuppression, typically by IDH mutant-specific peptide vaccine [135] or by using immune checkpoint inhibitors [133,136]. For example, cancer cells with the IDH1 R132H variant present a tumor-specific $\mathrm{CD}^{+}{ }^{+} \mathrm{T}$ cell neoepitope. Peptide vaccination targeting the IDH1 R132H mutation results in an effective anti-tumor immune response, and suppresses the growth of pre-established IDH1 R132H-mutated tumors [135]. Moreover, the inhibition of the mutant IDH neomorphic enzymatic activity improves the anti-tumor immunity of the IDH1-specific vaccine [134]. Vaccine-based immunotherapies have been developed based on the neoantigen targets in gliomas. For example, EGFR variant III (EGFRvIII) is the most common mutation in IDH1 wild-type GBMs. A peptide vaccine, rindopepimut (CDX-110), was developed to target this mutation. A recent phase III clinical trial showed that, although rindopepimut induced a decent humoral immune response, no significant survival benefit was observed [137-139]. Several IDH1 peptide vaccines are currently in early phase clinical trials (e.g., NCT02454634, NCT03893903, and NCT02193347), which should provide critical information regarding the safety and efficacy of this approach. Recently, applications of immune checkpoint inhibitors have been brought into the spotlight of clinical investigations [136]. However, in IDH mutant cancers, the immunosuppressive microenvironment might limit the therapeutic efficacy of immune checkpoint inhibitors. Bunse et al. reported that the inhibition of mutant IDH resulted in an enhanced anti-tumor effect of anti-PD-1 treatment [133].

\section{Conclusions-Current Knowledge and Opportunities for the Future}

In summary, significant amounts of effort and progress have been made over the past decade to understand the biology of $I D H$ mutations in glioma. A growing body of evidence has shown a correlation between IDH mutation and malignant transformation by altering cellular epigenetics, metabolism, DNA repair pathways, and redox homeostasis. This provides potential opportunities for targeting these pathways as therapeutic approaches to IDH mutant cancers, for example, targeting hypermethylation phenotype using epigenetic modulators [63,121,122]; targeting essential metabolic pathways, such as the NAD de novo synthesis pathway [131] or glutaminolysis [29,140]; targeting compromised DNA repair pathways in IDH mutant cancers [22,23,69,141]; and targeting redox regulators, such as NRF2 $[25,27,28,128]$. Moreover, with the increased knowledge of the molecular 
mechanism, targeting IDH mutations is suggested as a therapeutic approach to cancers bearing these mutations. Specific small molecular inhibitors of mutant IDH have been developed to inhibit the IDH mutant neomorphic activity [109]. Although several studies have reported some limitations to their application [23,142,143], mutant IDH inhibitors have still shown promising therapeutic benefits in numerous preclinical and clinical studies [116,144,145]. The recent development of glioma mouse models has provided generous insights regarding glioma biology and therapeutics [146]. An earlier study by Bardella et al. [32] showed that the mice with a IDH1 R132H expression developed hydrocephalus and grossly dilated lateral ventricles; however, only precursor lesions were observed. Several recent advances in IDH1 mutant mouse models have been developed, which are discussed in our recent review [53], along with increased evidence reflecting the potential value of targeting mutant IDH in cancer treatment. Thus, more efforts are needed to elucidate the role of IDH mutation in tumorigenesis and clinical translation.

Author Contributions: C.Y. contributed conceptual design. Y.L., F.L., F.-J.C., K.A.Z., and C.Y. composed the manuscript. All authors have read and agreed to the published version of the manuscript.

Funding: This work was supported by the Intramural Research Program of the National Institutes of Health, National Cancer Institute. This research received no external funding.

Conflicts of Interest: The authors declare no conflict of interest.

\section{References}

1. Parsons, D.W.; Jones, S.; Zhang, X.; Lin, J.C.-H.; Leary, R.J.; Angenendt, P.; Mankoo, P.; Carter, H.; Siu, I.-M.; Gallia, G.L.; et al. An Integrated Genomic Analysis of Human Glioblastoma Multiforme. Science 2008, 321, 1807-1812. [CrossRef]

2. Yan, H.; Parsons, D.W.; Jin, G.; McLendon, R.; Rasheed, B.A.; Yuan, W.; Kos, I.; Batinic-Haberle, I.; Jones, S.; Riggins, G.J.; et al. IDH1andIDH2Mutations in Gliomas. N. Engl. J. Med. 2009, 360, 765-773. [CrossRef]

3. Paschka, P.; Schlenk, R.F.; Gaidzik, V.I.; Habdank, M.; Krönke, J.; Bullinger, L.; Späth, D.; Kayser, S.; Zucknick, M.; Götze, K.; et al. IDH1 and IDH2 Mutations Are Frequent Genetic Alterations in Acute Myeloid Leukemia and Confer Adverse Prognosis in Cytogenetically Normal Acute Myeloid Leukemia With NPM1 Mutation Without FLT3 Internal Tandem Duplication. J. Clin. Oncol. 2010, 28, 3636-3643. [CrossRef] [PubMed]

4. Mardis, E.R.; Ding, L.; Dooling, D.J.; Larson, D.E.; McLellan, M.D.; Chen, K.; Koboldt, D.C.; Fulton, R.S.; Delehaunty, K.D.; McGrath, S.; et al. Recurring Mutations Found by Sequencing an Acute Myeloid Leukemia Genome. N. Engl. J. Med. 2009, 361, 1058-1066. [CrossRef] [PubMed]

5. Borger, D.R.; Tanabe, K.K.; Fan, K.C.; Lopez, H.U.; Fantin, V.R.; Straley, K.S.; Schenkein, D.P.; Hezel, A.F.; Ancukiewicz, M.; Liebman, H.M.; et al. Frequent Mutation of Isocitrate Dehydrogenase (IDH)1 and IDH2 in Cholangiocarcinoma Identified Through Broad-Based Tumor Genotyping. Oncologist 2011, 17, 72-79. [CrossRef] [PubMed]

6. Wang, F.; Travins, J.; DelaBarre, B.; Lacronique, V.; Schalm, S.; Hansen, E.; Straley, K.; Kernytsky, A.; Liu, W.; Gliser, C.; et al. Targeted Inhibition of Mutant IDH2 in Leukemia Cells Induces Cellular Differentiation. Science 2013, 340, 622-626. [CrossRef]

7. Amary, M.F.; Bácsi, K.; Maggiani, F.; Damato, S.; Halai, D.; Berisha, F.; Pollock, R.; O’Donnell, P.; Grigoriadis, A.; Diss, T.; et al. IDH1 and IDH2 mutations are frequent events in central chondrosarcoma and central and periosteal chondromas but not in other mesenchymal tumours. J. Pathol. 2011, 224, 334-343. [CrossRef]

8. Lopez, G.Y.; Reitman, Z.J.; Solomon, D.; Waldman, T.; Bigner, D.D.; McLendon, R.E.; A Rosenberg, S.; Samuels, Y.; Yan, H. IDH1 mutation identified in one human melanoma metastasis, but not correlated with metastases to the brain. Biochem. Biophys. Res. Commun. 2010, 398, 585-587. [CrossRef]

9. Shibata, T.; Kokubu, A.; Miyamoto, M.; Sasajima, Y.; Yamazaki, N. Mutant IDH1 Confers an in Vivo Growth in a Melanoma Cell Line with BRAF Mutation. Am. J. Pathol. 2011, 178, 1395-1402. [CrossRef]

10. Yan, H.; Bigner, D.D.; Velculescu, V.E.; Parsons, D.W. Mutant metabolic enzymes are at the origin of gliomas. Cancer Res. 2009, 69, 9157-9159. [CrossRef] 
11. Ward, P.S.; Patel, J.; Wise, D.R.; Abdel-Wahab, O.; Bennett, B.D.; Coller, H.A.; Cross, J.R.; Fantin, V.R.; Hedvat, C.V.; Perl, A.E.; et al. The Common Feature of Leukemia-Associated IDH1 and IDH2 Mutations Is a Neomorphic Enzyme Activity Converting $\alpha$-Ketoglutarate to 2-Hydroxyglutarate. Cancer Cell 2010, 17, 225-234. [CrossRef] [PubMed]

12. Dang, L.; Jin, S.; Su, S.M. IDH mutations in glioma and acute myeloid leukemia. Trends Mol. Med. 2010, 16, 387-397. [CrossRef] [PubMed]

13. Prensner, J.; Chinnaiyan, A.M. Metabolism unhinged: IDH mutations in cancer. Nat. Med. 2011, 17, $291-293$. [CrossRef] [PubMed]

14. Losman, J.-A.; Kaelin, W.G. What a difference a hydroxyl makes: Mutant IDH, (R)-2-hydroxyglutarate, and cancer. Genes Dev. 2013, 27, 836-852. [CrossRef] [PubMed]

15. Xu, W.; Yang, H.; Liu, Y.; Yang, Y.; Wang, P.; Kim, S.-H.; Ito, S.; Yang, C.; Wang, P.; Xiao, M.-T.; et al. Oncometabolite 2-Hydroxyglutarate Is a Competitive Inhibitor of $\alpha$-Ketoglutarate-Dependent Dioxygenases. Cancer Cell 2011, 19, 17-30. [CrossRef]

16. Chowdhury, R.; Yeoh, K.K.; Tian, Y.-M.; Hillringhaus, L.; Bagg, E.; Rose, N.R.; Leung, I.K.H.; Li, X.S.; Woon, E.C.Y.; Yang, M.; et al. The oncometabolite 2-hydroxyglutarate inhibits histone lysine demethylases. EMBO Rep. 2011, 12, 463-469. [CrossRef]

17. Lu, C.; Ward, P.S.; Kapoor, G.S.; Rohle, D.; Turcan, S..; Abdel-Wahab, O.; Edwards, C.R.; Khanin, R.; Figueroa, M.E.; Melnick, A.; et al. IDH mutation impairs histone demethylation and results in a block to cell differentiation. Nature 2012, 483, 474-478. [CrossRef]

18. Turcan, S..; Rohle, D.; Goenka, A.; A Walsh, L.; Fang, F.; Yilmaz, E.; Campos, C.; Fabius, A.W.M.; Lu, C.; Ward, P.S.; et al. IDH1 mutation is sufficient to establish the glioma hypermethylator phenotype. Nature 2012, 483, 479-483. [CrossRef]

19. Wang, P.; Wu, J.; Ma, S.; Zhang, L.; Yao, J.; Hoadley, K.A.; Wilkerson, M.D.; Perou, C.M.; Guan, K.-L.; Ye, D.; et al. Oncometabolite D-2-Hydroxyglutarate Inhibits ALKBH DNA Repair Enzymes and Sensitizes IDH Mutant Cells to Alkylating Agents. Cell Rep. 2015, 13, 2353-2361. [CrossRef]

20. Inoue, S.; Li, W.Y.; Tseng, A.; Beerman, I.; Elia, A.J.; Bendall, S.C.; Lemonnier, F.; Kron, K.J.; Cescon, D.W.; Hao, Z.; et al. Mutant IDH1 Downregulates ATM and Alters DNA Repair and Sensitivity to DNA Damage Independent of TET2. Cancer Cell 2016, 30, 337-348. [CrossRef]

21. Wang, Y.; Wild, A.T.; Turcan, S.; Wu, W.H.; Sigel, C.; Klimstra, D.S.; Ma, X.; Gong, Y.; Holland, E.C.; Huse, J.T.; et al. Targeting therapeutic vulnerabilities with PARP inhibition and radiation in IDH-mutant gliomas and cholangiocarcinomas. Sci. Adv. 2020, 6, eaaz3221. [CrossRef] [PubMed]

22. Lu, Y.; Kwintkiewicz, J.; Liu, Y.; Tech, K.; Frady, L.N.; Su, Y.-T.; Bautista, W.; Moon, S.I.; Macdonald, J.; Ewend, M.G.; et al. Chemosensitivity of IDH1-Mutated Gliomas Due to an Impairment in PARP1-Mediated DNA Repair. Cancer Res. 2017, 77, 1709-1718. [CrossRef] [PubMed]

23. Sulkowski, P.L.; Corso, C.D.; Robinson, N.D.; Scanlon, S.E.; Purshouse, K.; Bai, H.; Liu, Y.; Sundaram, R.K.; Hegan, D.C.; Fons, N.R.; et al. 2-Hydroxyglutarate produced by neomorphic IDH mutations suppresses homologous recombination and induces PARP inhibitor sensitivity. Sci. Transl. Med. 2017, 9, eaal2463. [CrossRef] [PubMed]

24. Shi, J.; Sun, B.; Shi, W.; Zuo, H.; Cui, D.; Ni, L.; Chen, J. Decreasing GSH and increasing ROS in chemosensitivity gliomas with IDH1 mutation. Tumor Boil. 2014, 36, 655-662. [CrossRef] [PubMed]

25. Tang, X.; Fu, X.; Liu, Y.; Yu, D.; Cai, S.J.; Yang, C. Blockade of Glutathione Metabolism in IDH1-Mutated Glioma. Mol. Cancer Ther. 2019, 19, 221-230. [CrossRef] [PubMed]

26. Gelman, S.J.; Naser, F.; Mahieu, N.G.; McKenzie, L.D.; Dunn, G.P.; Chheda, M.G.; Patti, G.J. Consumption of NADPH for 2-HG Synthesis Increases Pentose Phosphate Pathway Flux and Sensitizes Cells to Oxidative Stress. Cell Rep. 2018, 22, 512-522. [CrossRef]

27. Yu, D.; Liu, Y.; Zhou, Y.; Ruiz-Rodado, V.; Larion, M.; Xu, G.; Yang, C. Triptolide suppresses IDH1-mutated malignancy via Nrf2-driven glutathione metabolism. Proc. Natl. Acad. Sci. USA 2020, 117, 9964-9972. [CrossRef]

28. Liu, Y.; Lu, Y.; Celiku, O.; Li, A.; Wu, Q.; Zhou, Y.; Yang, C. Targeting IDH1-Mutated Malignancies with NRF2 Blockade. J. Natl. Cancer Inst. 2019, 111, 1033-1041. [CrossRef]

29. McBrayer, S.K.; Mayers, J.R.; DiNatale, G.J.; Shi, D.D.; Khanal, J.; Chakraborty, A.A.; Sarosiek, K.; Briggs, K.J.; Robbins, A.K.; Sewastianik, T.; et al. Transaminase Inhibition by 2-Hydroxyglutarate Impairs Glutamate Biosynthesis and Redox Homeostasis in Glioma. Cell 2018, 175, 101-116.e25. [CrossRef] 
30. Suzuki, H.; Aoki, K.; Chiba, K.; Sato, Y.; Shiozawa, Y.; Shiraishi, Y.; Shimamura, T.; Niida, A.; Motomura, K.; Ohka, F.; et al. Mutational landscape and clonal architecture in grade II and III gliomas. Nat. Genet. 2015, 47, 458-468. [CrossRef]

31. Philip, B.; Yu, D.X.; Silvis, M.R.; Shin, C.H.; Robinson, J.P.; Robinson, G.L.; Welker, A.E.; Angel, S.N.; Tripp, S.R.; Sonnen, J.A.; et al. Mutant IDH1 Promotes Glioma Formation In Vivo. Cell Rep. 2018, 23, 1553-1564. [CrossRef] [PubMed]

32. Bardella, C.; Al-Dalahmah, O.; Krell, D.; Brazauskas, P.; Al-Qahtani, K.; Tomkova, M.; Adam, J.; Serres, S.; Lockstone, H.; Freeman-Mills, L.; et al. Expression of Idh1R132H in the Murine Subventricular Zone Stem Cell Niche Recapitulates Features of Early Gliomagenesis. Cancer Cell 2016, 30, 578-594. [CrossRef] [PubMed]

33. Chung, R.; Whaley, J.; Kley, N.; Anderson, K.; Louis, D.; Menon, A.; Hettlich, C.; Freiman, R.; Hedley-Whyte, E.T.; Martuza, R.; et al. TP53 Gene Mutations and 17p Deletions in Human Astrocytomas. Genes Chromosom. Cancer 1991, 3, 323-331. [CrossRef] [PubMed]

34. Rasheed, B.K.; E McLendon, R.; E Herndon, J.; Friedman, H.S.; Friedman, A.H.; Bigner, D.D.; Bigner, S.H. Alterations of the TP53 gene in human gliomas. Cancer Res. 1994, 54, 1324-1330.

35. Killela, P.J.; Pirozzi, C.J.; Reitman, Z.J.; Jones, S.; Rasheed, B.A.; Lipp, E.S.; Friedman, H.; Friedman, A.H.; He, Y.; McLendon, R.E.; et al. The genetic landscape of anaplastic astrocytoma. Oncotarget 2013, 5, 1452-1457. [CrossRef]

36. Killela, P.J.; Reitman, Z.J.; Jiao, Y.; Bettegowda, C.; Agrawal, N.; Diaz, L.A.; Friedman, A.H.; Friedman, H.; Gallia, G.L.; Giovanella, B.C.; et al. TERT promoter mutations occur frequently in gliomas and a subset of tumors derived from cells with low rates of self-renewal. Proc. Natl. Acad. Sci. USA 2013, 110, 6021-6026. [CrossRef]

37. Bettegowda, C.; Agrawal, N.; Jiao, Y.; Sausen, M.; Wood, L.D.; Hruban, R.H.; Rodriguez, F.J.; Cahill, D.P.; McLendon, R.; Riggins, G.; et al. Mutations in CIC and FUBP1 Contribute to Human Oligodendroglioma. Science 2011, 333, 1453-1455. [CrossRef]

38. Jiao, Y.; Killela, P.J.; Reitman, Z.J.; Rasheed, B.A.; Heaphy, C.M.; De Wilde, R.F.; Rodriguez, F.J.; Rosemberg, S.; Oba-Shinjo, S.M.; Marie, S.K.N.; et al. Frequent ATRX, CIC, FUBP1 and IDH1 mutations refine the classification of malignant gliomas. Oncotarget 2012, 3, 709-722. [CrossRef]

39. Cairncross, J.G.; Ueki, K.; Zlatescu, M.C.; Lisle, D.K.; Finkelstein, D.M.; Hammond, R.R.; Silver, J.S.; Stark, P.C.; Macdonald, D.R.; Ino, Y.; et al. Specific genetic predictors of chemotherapeutic response and survival in patients with anaplastic oligodendrogliomas. J. Natl. Cancer Inst. 1998, 90, 1473-1479. [CrossRef]

40. Labussière, M.; Idbaih, A.; Wang, X.; Marie, Y.; Boisselier, B.; Falet, C.; Paris, S.; Laffaire, J.; Carpentier, C.; Criniere, E.; et al. All the 1p19q codeleted gliomas are mutated on IDH1 or IDH2. Neurology 2010, 74, 1886-1890. [CrossRef]

41. Sahm, F.; Koelsche, C.; Meyer, J.; Pusch, S.; Lindenberg, K.; Mueller, W.; Herold-Mende, C.; Von Deimling, A.; Hartmann, C. CIC and FUBP1 mutations in oligodendrogliomas, oligoastrocytomas and astrocytomas. Acta Neuropathol. 2012, 123, 853-860. [CrossRef] [PubMed]

42. Killela, P.J.; Pirozzi, C.J.; Healy, P.; Reitman, Z.J.; Lipp, E.S.; Rasheed, B.A.; Yang, R.; Diplas, B.; Wang, Z.; Greer, P.K.; et al. Mutations in IDH1, IDH2, and in the TERT promoter define clinically distinct subgroups of adult malignant gliomas. Oncotarget 2014, 5, 1515-1525. [CrossRef] [PubMed]

43. Brito, C.; Azevedo, A.; Esteves, S.; Marques, A.R.; Martins, C.; Costa, I.; Mafra, M.; Marques, J.M.B.; Roque, L.; Pojo, M. Clinical insights gained by refining the 2016 WHO classification of diffuse gliomas with: EGFR amplification, TERT mutations, PTEN deletion and MGMT methylation. BMC Cancer 2019, 19, 968. [CrossRef] [PubMed]

44. Noorani, I.; De La Rosa, J.; Choi, Y.H.; Strong, A.; Ponstingl, H.; Vijayabaskar, M.S.; Lee, J.; Lee, E.; Richard-Londt, A.; Friedrich, M.; et al. PiggyBac mutagenesis and exome sequencing identify genetic driver landscapes and potential therapeutic targets of EGFR-mutant gliomas. Genome Boil. 2020, 21, 1-36. [CrossRef]

45. Louis, D.N.; Perry, A.; Reifenberger, G.; Von Deimling, A.; Figarella-Branger, M.; Cavenee, W.K.; Ohgaki, H.; Wiestler, O.D.; Kleihues, P.; Ellison, D.W. The 2016 World Health Organization Classification of Tumors of the Central Nervous System: A summary. Acta Neuropathol. 2016, 131, 803-820. [CrossRef] [PubMed]

46. Cerami, E.; Gao, J.; Dogrusoz, U.; Gross, B.E.; Sumer, S.O.; Aksoy, B.A.; Skanderup, A.J.; Byrne, C.J.; Heuer, M.L.; Larsson, E.; et al. The cBio Cancer Genomics Portal: An Open Platform for Exploring Multidimensional Cancer Genomics Data: Figure 1. Cancer Discov. 2012, 2, 401-404. [CrossRef] 
47. Gao, J.; Aksoy, B.A.; Dogrusoz, U.; Dresdner, G.; Gross, B.; Sumer, S.O.; Sun, Y.; Skanderup, A.J.; Sinha, R.; Larsson, E.; et al. Integrative Analysis of Complex Cancer Genomics and Clinical Profiles Using the cBioPortal. Sci. Signal. 2013, 6, p11. [CrossRef]

48. Noushmehr, H.; Weisenberger, D.J.; Diefes, K.; Phillips, H.S.; Pujara, K.; Berman, B.P.; Pan, F.; Pelloski, C.E.; Sulman, E.P.; Bhat, K.P.; et al. Identification of a CpG Island Methylator Phenotype that Defines a Distinct Subgroup of Glioma. Cancer Cell 2010, 17, 510-522. [CrossRef]

49. Christensen, B.C.; Smith, A.A.; Zheng, S.; Koestler, D.C.; Houseman, E.A.; Marsit, C.J.; Wiemels, J.L.; Nelson, H.; Karagas, M.R.; Wrensch, M.R.; et al. DNA Methylation, Isocitrate Dehydrogenase Mutation, and Survival in Glioma. J. Natl. Cancer Inst. 2011, 103, 143-153. [CrossRef]

50. Turcan, S..; Makarov, V.; Taranda, J.; Wang, Y.; Fabius, A.W.M.; Wu, W.; Zheng, Y.; El-Amine, N.; Haddock, S.; Nanjangud, G.; et al. Mutant-IDH1-dependent chromatin state reprogramming, reversibility, and persistence. Nat. Genet. 2017, 50, 62-72. [CrossRef]

51. De Souza, C.F.; Sabedot, T.S.; Malta, T.M.; Stetson, L.; Morozova, O.; Sokolov, A.; Laird, P.W.; Wiznerowicz, M.; Iavarone, A.; Snyder, J.; et al. A Distinct DNA Methylation Shift in a Subset of Glioma CpG Island Methylator Phenotypes during Tumor Recurrence. Cell Rep. 2018, 23, 637-651. [CrossRef] [PubMed]

52. Adler, E.; Euler, H.V.; Günther, G.; Plass, M. isoCitric dehydrogenase and glutamic acid synthesis in animal tissues. Biochem. J. 1939, 33, 1028-1045. [CrossRef] [PubMed]

53. Han, S.; Liu, Y.; Cai, S.J.; Qian, M.; Ding, J.; Larion, M.; Gilbert, M.R.; Yang, C. IDH mutation in glioma: Molecular mechanisms and potential therapeutic targets. Br. J. Cancer 2020, 122, 1580-1589. [CrossRef] [PubMed]

54. Sun, P.; Ma, T.; Zhang, T.; Zhu, H.; Zhang, J.; Liu, Y.; Ding, J. Molecular basis for the function of the $\alpha \beta$ heterodimer of human NAD-dependent isocitrate dehydrogenase. J. Boil. Chem. 2019, 294, 16214-16227. [CrossRef]

55. Rendina, A.R.; Pietrak, B.; Smallwood, A.; Zhao, H.J.; Qi, H.; Quinn, C.; Adams, N.D.; Concha, N.; Duraiswami, C.; Thrall, S.H.; et al. Mutant IDH1 Enhances the Production of 2-Hydroxyglutarate Due to Its Kinetic Mechanism. Biochemistry 2013, 52, 4563-4577. [CrossRef]

56. Tate, J.G.; Bamford, S.; Jubb, H.C.; Sondka, Z.; Beare, D.M.; Bindal, N.; Boutselakis, H.; Cole, C.G.; Creatore, C.; Dawson, E.; et al. COSMIC: The Catalogue Of Somatic Mutations In Cancer. Nucleic Acids Res. 2018, 47, D941-D947. [CrossRef]

57. Xu, X.; Zhao, J.; Xu, Z.; Peng, B.; Huang, Q.; Arnold, E.; Ding, J. Structures of Human Cytosolic NADP-dependent Isocitrate Dehydrogenase Reveal a Novel Self-regulatory Mechanism of Activity. J. Boil. Chem. 2004, 279, 33946-33957. [CrossRef]

58. Dang, L.; White, D.W.; Gross, S.; Bennett, B.D.; Bittinger, M.A.; Driggers, E.M.; Fantin, V.R.; Jang, H.G.; Jin, S.; Keenan, M.C.; et al. Cancer-associated IDH1 mutations produce 2-hydroxyglutarate. Nature 2010, 465, 966. [CrossRef]

59. Jin, G.; Reitman, Z.J.; Spasojevic, I.; Batinic-Haberle, I.; Yang, J.; Schmidt-Kittler, O.; Bigner, D.D.; Yan, H. 2-Hydroxyglutarate Production, but Not Dominant Negative Function, Is Conferred by Glioma-Derived NADP+-Dependent Isocitrate Dehydrogenase Mutations. PLoS ONE 2011, 6, e16812. [CrossRef]

60. Laukka, T.; Myllykoski, M.; Looper, R.E.; Koivunen, P. Cancer-associated 2-oxoglutarate analogues modify histone methylation by inhibiting histone lysine demethylases. J. Mol. Boil. 2018, 430, 3081-3092. [CrossRef]

61. Janke, R.; Iavarone, A.T.; Rine, J. Oncometabolite D-2-Hydroxyglutarate enhances gene silencing through inhibition of specific H3K36 histone demethylases. eLife 2017, 6, e22451. [CrossRef] [PubMed]

62. Figueroa, M.E.; Abdel-Wahab, O.; Lu, C.; Ward, P.S.; Patel, J.; Shih, A.; Li, Y.; Bhagwat, N.; VasanthaKumar, A.; Fernandez, H.F.; et al. Leukemic IDH1 and IDH2 mutations result in a hypermethylation phenotype, disrupt TET2 function, and impair hematopoietic differentiation. Cancer Cell 2010, 18, 553-567. [CrossRef] [PubMed]

63. Flavahan, W.A.; Drier, Y.; Liau, B.B.; Gillespie, S.M.; Venteicher, A.S.; Stemmer-Rachamimov, A.O.; Suvà, M.L.; Bernstein, B.E. Insulator dysfunction and oncogene activation in IDH mutant gliomas. Nature 2015, 529, 110-114. [CrossRef] [PubMed]

64. Curtin, N.J. DNA repair dysregulation from cancer driver to therapeutic target. Nat. Rev. Cancer 2012, 12, 801-817. [CrossRef]

65. Chatterjee, N.; Walker, G.C. Mechanisms of DNA damage, repair, and mutagenesis. Environ. Mol. Mutagen. 2017, 58, 235-263. [CrossRef] 
66. Polo, S.; Jackson, S.P. Dynamics of DNA damage response proteins at DNA breaks: A focus on protein modifications. Genes Dev. 2011, 25, 409-433. [CrossRef]

67. Ohba, S.; Mukherjee, J.; See, W.L.; Pieper, R.O. Mutant IDH1-Driven Cellular Transformation Increases RAD51-Mediated Homologous Recombination and Temozolomide Resistance. Cancer Res. 2014, 74, 4836-4844. [CrossRef]

68. Núñez, F.J.; Mendez, F.M.; Kadiyala, P.; AlGhamri, M.S.; Savelieff, M.G.; Garcia-Fabiani, M.B.; Haase, S.; Koschmann, C.; Calinescu, A.-A.; Kamran, N.; et al. IDH1-R132H acts as a tumor suppressor in glioma via epigenetic up-regulation of the DNA damage response. Sci. Transl. Med. 2019, 11, eaaq1427. [CrossRef]

69. Lu, Y.; Liu, Y.; Pang, Y.; Pacak, K.; Yang, C. Double-barreled gun: Combination of PARP inhibitor with conventional chemotherapy. Pharmacol. Ther. 2018, 188, 168-175. [CrossRef]

70. Sulkowski, P.L.; Oeck, S.; Dow, J.; Economos, N.G.; Mirfakhraie, L.; Liu, Y.; Noronha, K.; Bao, X.; Li, J.; Shuch, B.M.; et al. Oncometabolites suppress DNA repair by disrupting local chromatin signalling. Nature 2020, 582, 586-591. [CrossRef]

71. Grassian, A.R.; Parker, S.J.; Davidson, S.M.; Divakaruni, A.S.; Green, C.R.; Zhang, X.; Slocum, K.L.; Pu, M.; Lin, F.; Vickers, C.; et al. IDH1 mutations alter citric acid cycle metabolism and increase dependence on oxidative mitochondrial metabolism. Cancer Res. 2014, 74, 3317-3331. [CrossRef] [PubMed]

72. Reitman, Z.J.; Jin, G.; Karoly, E.D.; Spasojevic, I.; Yang, J.; Kinzler, K.W.; He, Y.; Bigner, D.D.; Vogelstein, B.; Yan, H. Profiling the effects of isocitrate dehydrogenase 1 and 2 mutations on the cellular metabolome. Proc. Natl. Acad. Sci. USA 2011, 108, 3270-3275. [CrossRef] [PubMed]

73. Ohka, F.; Ito, M.; Ranjit, M.; Senga, T.; Motomura, A.; Motomura, K.; Saito, K.; Kato, K.; Kato, Y.; Wakabayashi, T.; et al. Quantitative metabolome analysis profiles activation of glutaminolysis in glioma with IDH1 mutation. Tumor Boil. 2014, 35, 5911-5920. [CrossRef] [PubMed]

74. Seltzer, M.J.; Bennett, B.D.; Joshi, A.D.; Gao, P.; Thomas, A.G.; Ferraris, D.; Tsukamoto, T.; Rojas, C.J.; Slusher, B.S.; Rabinowitz, J.D.; et al. Inhibition of glutaminase preferentially slows growth of glioma cells with mutant IDH1. Cancer Res. 2010, 70, 8981-8987. [CrossRef]

75. Wen, P.Y.; Huse, J.T. 2016 World Health Organization Classification of Central Nervous System Tumors. Contin. Lifelong Learn. Neurol. 2017, 23, 1531-1547. [CrossRef]

76. Riemenschneider, M.J.; Jeuken, J.W.M.; Wesseling, P.; Reifenberger, G. Molecular diagnostics of gliomas: State of the art. Acta Neuropathol. 2010, 120, 567-584. [CrossRef]

77. Chen, R.; Smith-Cohn, M.; Cohen, A.L.; Colman, H. Glioma Subclassifications and Their Clinical Significance. Neurotherapeutics 2017, 14, 284-297. [CrossRef]

78. Jaunmuktane, Z.; Capper, D.; Jones, D.T.W.; Schrimpf, D.; Sill, M.; Dutt, M.; Suraweera, N.; Pfister, S.M.; Von Deimling, A.; Brandner, S. Methylation array profiling of adult brain tumours: Diagnostic outcomes in a large, single centre. Acta Neuropathol. Commun. 2019, 7, 24. [CrossRef]

79. Andronesi, O.C.; Rapalino, O.; Gerstner, E.; Chi, A.; Batchelor, T.T.; Cahill, D.P.; Sorensen, A.G.; Rosen, B.R. Detection of oncogenic IDH1 mutations using magnetic resonance spectroscopy of 2-hydroxyglutarate. J. Clin. Investig. 2013, 123, 3659-3663. [CrossRef]

80. Andronesi, O.C.; Kim, G.S.; Gerstner, E.; Batchelor, T.; Tzika, A.A.; Fantin, V.R.; Heiden, M.G.V.; Sorensen, A.G. Detection of 2-Hydroxyglutarate in IDH-Mutated Glioma Patients by In Vivo Spectral-Editing and 2D Correlation Magnetic Resonance Spectroscopy. Sci. Transl. Med. 2012, 4, 116ra4. [CrossRef]

81. Pope, W.B.; Prins, R.M.; Thomas, M.A.; Nagarajan, R.; Yen, K.E.; Bittinger, M.A.; Salamon, N.; Chou, A.P.; Yong, W.H.; Soto, H.; et al. Non-invasive detection of 2-hydroxyglutarate and other metabolites in IDH1 mutant glioma patients using magnetic resonance spectroscopy. Neuro-Oncology 2011, 107, 197-205. [CrossRef] [PubMed]

82. Natsumeda, M.; Igarashi, H.; Nomura, T.; Ogura, R.; Tsukamoto, Y.; Kobayashi, T.; Aoki, H.; Okamoto, K.; Kakita, A.; Takahashi, H.; et al. Accumulation of 2-hydroxyglutarate in gliomas correlates with survival: A study by 3.0-tesla magnetic resonance spectroscopy. Acta Neuropathol. Commun. 2014, 2, 158. [CrossRef] [PubMed]

83. Lazovic, J.; Soto, H.; Piccioni, D.E.; Ru, J.R.L.; Li, S.; Mirsadraei, L.; Yong, W.; Prins, R.M.; Liau, L.M.; Ellingson, B.M.; et al. Detection of 2-hydroxyglutaric acid in vivo by proton magnetic resonance spectroscopy in U87 glioma cells overexpressing isocitrate dehydrogenase-1 mutation. Neuro-Oncology 2012, 14, 1465-1472. [CrossRef] [PubMed] 
84. Heo, H.; Kim, S.; Lee, H.H.; Cho, H.R.; Xu, W.J.; Lee, S.-H.; Park, C.K.; Park, S.; Choi, S.H.; Kim, H. On the Utility of Short Echo Time (TE) Single Voxel 1H-MRS in Non-Invasive Detection of 2-Hydroxyglutarate (2HG); Challenges and Potential Improvement Illustrated with Animal Models Using MRUI and LCModel. PLOS ONE 2016, 11, e0147794. [CrossRef]

85. Choi, C.; Ganji, S.K.; DeBerardinis, R.J.; Hatanpaa, K.J.; Rakheja, D.; Kovacs, Z.; Yang, X.-L.; Mashimo, T.; Raisanen, J.M.; Marin-Valencia, I.; et al. 2-hydroxyglutarate detection by magnetic resonance spectroscopy in IDH-mutated patients with gliomas. Nat. Med. 2012, 18, 624-629. [CrossRef]

86. Choi, C.; Ganji, S.; Hulsey, K.; Madan, A.; Kovacs, Z.; Dimitrov, I.; Zhang, S.; Pichumani, K.; Mendelsohn, D.; Mickey, B.; et al. A comparative study of short- and long-TE ${ }^{1} \mathrm{H}$ MRS at $3 \mathrm{~T}$ for in vivo detection of 2-hydroxyglutarate in brain tumors. NMR Biomed. 2013, 26, 1242-1250. [CrossRef]

87. De La Fuente, M.I.; Young, R.J.; Rubel, J.; Rosenblum, M.; Tisnado, J.; Briggs, S.; Pérez, J.A.; Cross, J.R.; Campos, C.; Straley, K.; et al. Integration of 2-hydroxyglutarate-proton magnetic resonance spectroscopy into clinical practice for disease monitoring in isocitrate dehydrogenase-mutant glioma. Neuro-Oncology 2015, 18, 283-290. [CrossRef]

88. Emir, U.E.; Larkin, S.J.; De Pennington, N.; Voets, N.L.; Plaha, P.; Stacey, R.; Al-Qahtani, K.; Mccullagh, J.S.; Schofield, C.J.; Clare, S.; et al. Noninvasive Quantification of 2-Hydroxyglutarate in Human Gliomas with IDH1 and IDH2 Mutations. Cancer Res. 2015, 76, 43-49. [CrossRef]

89. Sanson, M.; Marie, Y.; Paris, S.; Idbaih, A.; Laffaire, J.; Ducray, F.; El Hallani, S.; Boisselier, B.; Mokhtari, K.; Hoang-Xuan, K.; et al. Isocitrate Dehydrogenase 1 Codon 132 Mutation Is an Important Prognostic Biomarker in Gliomas. J. Clin. Oncol. 2009, 27, 4150-4154. [CrossRef]

90. Brennan, C.W.; Verhaak, R.G.; McKenna, A.; Campos, B.; Noushmehr, H.; Salama, S.R.; Zheng, S.; Chakravarty, D.; Sanborn, J.Z.; Berman, S.H.; et al. The Somatic Genomic Landscape of Glioblastoma. Cell 2013, 155, 462-477. [CrossRef]

91. Nobusawa, S.; Watanabe, T.; Kleihues, P.; Ohgaki, H. IDH1 Mutations as Molecular Signature and Predictive Factor of Secondary Glioblastomas. Clin. Cancer Res. 2009, 15, 6002-6007. [CrossRef] [PubMed]

92. Toedt, G.; Barbus, S.; Wolter, M.; Felsberg, J.; Tews, B.; Blond, F.; Sabel, M.; Hofmann, S.; Becker, N.; Hartmann, C.; et al. Molecular signatures classify astrocytic gliomas byIDH1mutation status. Int. J. Cancer 2010, 128, 1095-1103. [CrossRef] [PubMed]

93. Weller, M.; Felsberg, J.; Hartmann, C.; Berger, H.; Steinbach, J.P.; Schramm, J.; Westphal, M.; Schackert, G.; Simon, M.; Tonn, J.C.; et al. Molecular Predictors of Progression-Free and Overall Survival in Patients With Newly Diagnosed Glioblastoma: A Prospective Translational Study of the German Glioma Network. J. Clin. Oncol. 2009, 27, 5743-5750. [CrossRef] [PubMed]

94. Lai, A.; Kharbanda, S.; Pope, W.B.; Tran, A.; Solis, O.E.; Peale, F.; Forrest, W.F.; Pujara, K.; Carrillo, J.A.; Pandita, A.; et al. Evidence for Sequenced Molecular Evolution of IDH1 Mutant Glioblastoma From a Distinct Cell of Origin. J. Clin. Oncol. 2011, 29, 4482-4490. [CrossRef]

95. Balss, J.; Meyer, J.; Mueller, W.; Korshunov, A.; Hartmann, C.; Von Deimling, A. Analysis of the IDH1 codon 132 mutation in brain tumors. Acta Neuropathol. 2008, 116, 597-602. [CrossRef]

96. Chaichana, K.L.; Parker, S.L.; Olivi, A.; Quinones-Hinojosa, A. Long-term seizure outcomes in adult patients undergoing primary resection of malignant brain astrocytomas. J. Neurosurg. 2009, 111, 282-292. [CrossRef]

97. Chang, E.F.; Potts, M.B.; Keles, G.E.; Lamborn, K.R.; Chang, S.M.; Barbaro, N.M.; Berger, M.S. Seizure characteristics and control following resection in 332 patients with low-grade gliomas. J. Neurosurg. 2008, 108, 227-235. [CrossRef]

98. Kerkhof, M.; Vecht, C.J. Seizure characteristics and prognostic factors of gliomas. Epilepsia 2013, 54, 12-17. [CrossRef]

99. Van Breemen, M.S.; Wilms, E.B.; Vecht, C.J. Epilepsy in patients with brain tumours: Epidemiology, mechanisms, and management. Lancet Neurol. 2007, 6, 421-430. [CrossRef]

100. Klein, M.; Engelberts, N.H.J.; Van Der Ploeg, H.M.; Trenité, D.G.A.K.-N.; Aaronson, N.K.; Taphoorn, M.J.B.; Baaijen, H.; Vandertop, W.P.; Müller, M.; Postma, T.J.; et al. Epilepsy in low-grade gliomas: The impact on cognitive function and quality of life. Ann. Neurol. 2003, 54, 514-520. [CrossRef]

101. Stockhammer, F.; Misch, M.; Helms, H.-J.; Lengler, U.; Prall, F.; Von Deimling, A.; Hartmann, C. IDH1/2 mutations in WHO grade II astrocytomas associated with localization and seizure as the initial symptom. Seizure 2012, 21, 194-197. [CrossRef] [PubMed] 
102. Liubinas, S.V.; D’Abaco, G.M.; Moffat, B.M.; Gonzales, M.; Feleppa, F.; Nowell, C.J.; Gorelik, A.; Drummond, K.J.; O'Brien, T.J.; Kaye, A.H.; et al. IDH1 mutation is associated with seizures and protoplasmic subtype in patients with low-grade gliomas. Epilepsia 2014, 55, 1438-1443. [CrossRef] [PubMed]

103. Yang, Y.; Qing, M.; Wang, X.; Liu, Y.; Mao, Y.; Zhou, Q.; Luo, J. An analysis of 170 glioma patients and systematic review to investigate the association between IDH-1 mutations and preoperative glioma-related epilepsy. J. Clin. Neurosci. 2016, 31, 56-62. [CrossRef] [PubMed]

104. Chen, H.; Judkins, J.; Thomas, C.; Wu, M.; Khoury, L.; Benjamin, C.; Pacione, D.; Golfinos, J.G.; Kumthekar, P.; Ghamsari, F.; et al. Mutant IDH1 and seizures in patients with glioma. Neurology 2017, 88, 1805-1813. [CrossRef] [PubMed]

105. Toledo, M.; Sarria-Estrada, S.; Quintana, M.; Maldonado, X.; Martínez-Ricarte, F.; Rodon, J.; Auger, C.; Aizpurua, M.; Salas-Puig, J.; Santamarina, E.; et al. Epileptic features and survival in glioblastomas presenting with seizures. Epilepsy Res. 2017, 130, 1-6. [CrossRef] [PubMed]

106. Moussawi, K.; Riegel, A.; Nair, S.; Kalivas, P.W. Extracellular Glutamate: Functional Compartments Operate in Different Concentration Ranges. Front. Syst. Neurosci. 2011, 5, 94. [CrossRef]

107. Elkhaled, A.; Jalbert, L.; Constantin, A.; Yoshihara, H.A.I.; Phillips, J.J.; Molinaro, A.M.; Chang, S.M.; Nelson, S.J. Characterization of metabolites in infiltrating gliomas usingex vivo1H high-resolution magic angle spinning spectroscopy. NMR Biomed. 2014, 27, 578-593. [CrossRef]

108. Vaarmann, A.; Kovac, S.; Holmstrom, K.; Gandhi, S.; Abramov, A.Y. Dopamine protects neurons against glutamate-induced excitotoxicity. Cell Death Dis. 2013, 4, e455. [CrossRef]

109. Rohle, D.; Popovici-Muller, J.; Palaskas, N.; Turcan, S..; Grommes, C.; Campos, C.; Tsoi, J.; Clark, O.; Oldrini, B.; Komisopoulou, E.; et al. An Inhibitor of Mutant IDH1 Delays Growth and Promotes Differentiation of Glioma Cells. Science 2013, 340, 626-630. [CrossRef]

110. Hartmann, C.; Hentschel, B.; Wick, W.; Capper, D.; Felsberg, J.; Simon, M.; Westphal, M.; Schackert, G.; Meyermann, R.; Pietsch, T.; et al. Patients with IDH1 wild type anaplastic astrocytomas exhibit worse prognosis than IDH1-mutated glioblastomas, and IDH1 mutation status accounts for the unfavorable prognostic effect of higher age: Implications for classification of gliomas. Acta Neuropathol. 2010, 120, 707-718. [CrossRef]

111. Houillier, C.; Wang, X.; Kaloshi, G.; Mokhtari, K.; Guillevin, R.; Laffaire, J.; Paris, S.; Boisselier, B.; Idbaih, A.; Laigle-Donadey, F.; et al. IDH1 or IDH2 mutations predict longer survival and response to temozolomide in low-grade gliomas. Neurology 2010, 75, 1560-1566. [CrossRef] [PubMed]

112. Hartmann, C.; Hentschel, B.; Tatagiba, M.; Schramm, J.; Schnell, O.; Seidel, C.; Stein, R.; Reifenberger, G.; Pietsch, T.; Von Deimling, A.; et al. Molecular Markers in Low-Grade Gliomas: Predictive or Prognostic? Clin. Cancer Res. 2011, 17, 4588-4599. [CrossRef] [PubMed]

113. Bent, M.J.V.D.; Dubbink, H.J.; Marie, Y.; Brandes, A.A.; Taphoorn, M.J.; Wesseling, P.; Frenay, M.; Tijssen, C.C.; Lacombe, D.; Idbaih, A.; et al. IDH1 and IDH2 Mutations Are Prognostic but not Predictive for Outcome in Anaplastic Oligodendroglial Tumors: A Report of the European Organization for Research and Treatment of Cancer Brain Tumor Group. Clin. Cancer Res. 2010, 16, 1597-1604. [CrossRef] [PubMed]

114. Popovici-Muller, J.; Saunders, J.O.; Salituro, F.G.; Travins, J.M.; Yan, S.; Zhao, F.; Gross, S.; Dang, L.; Yen, K.E.; Yang, H.; et al. Discovery of the First Potent Inhibitors of Mutant IDH1 That Lower Tumor 2-HG in Vivo. ACS Med. Chem. Lett. 2012, 3, 850-855. [CrossRef] [PubMed]

115. Dinardo, C.; Stein, E.M.; De Botton, S.; Roboz, G.J.; Altman, J.K.; Mims, A.S.; Swords, R.; Collins, R.H.; Mannis, G.N.; Pollyea, D.A.; et al. Durable Remissions with Ivosidenib inIDH1-Mutated Relapsed or Refractory AML. N. Engl. J. Med. 2018, 378, 2386-2398. [CrossRef] [PubMed]

116. Konteatis, Z.; Artin, E.; Nicolay, B.; Straley, K.; Padyana, A.K.; Jin, L.; Chen, Y.; Narayaraswamy, R.; Tong, S.; Wang, F.; et al. Vorasidenib (AG-881): A First-in-Class, Brain-Penetrant Dual Inhibitor of Mutant IDH1 and 2 for Treatment of Glioma. ACS Med. Chem. Lett. 2020, 11, 101-107. [CrossRef]

117. Fan, B.; Mellinghoff, I.K.; Wen, P.Y.; Lowery, M.A.; Goyal, L.; Tap, W.D.; Pandya, S.S.; Manyak, E.; Jiang, L.; Liu, G.; et al. Clinical pharmacokinetics and pharmacodynamics of ivosidenib, an oral, targeted inhibitor of mutant IDH1, in patients with advanced solid tumors. Investig. New Drugs 2019, 38, 433-444. [CrossRef]

118. Popovici-Muller, J.; Lemieux, R.M.; Artin, E.; Saunders, J.O.; Salituro, F.G.; Travins, J.; Cianchetta, G.; Cai, Z.; Zhou, D.; Cui, D.; et al. Discovery of AG-120 (Ivosidenib): A First-in-Class Mutant IDH1 Inhibitor for the Treatment of IDH1 Mutant Cancers. ACS Med. Chem. Lett. 2018, 9, 300-305. [CrossRef] 
119. Mellinghoff, I.K.; Ellingson, B.M.; Touat, M.; Maher, E.; De La Fuente, M.I.; Holdhoff, M.; Cote, G.M.; Burris, H.; Janku, F.; Young, R.J.; et al. Ivosidenib in Isocitrate Dehydrogenase 1-Mutated Advanced Glioma. J. Clin. Oncol. 2020, JCO1903327. [CrossRef]

120. Molenaar, R.J.; Radivoyevitch, T.; Nagata, Y.; Khurshed, M.; Przychodzen, B.; Makishima, H.; Xu, M.; Bleeker, F.E.; Wilmink, J.W.; Carraway, H.E.; et al. IDH1/2Mutations Sensitize Acute Myeloid Leukemia to PARP Inhibition and This Is Reversed by IDH1/2-Mutant Inhibitors. Clin. Cancer Res. 2018, 24, 1705-1715. [CrossRef]

121. Borodovsky, A.; Salmasi, V.; Turcan, Ş.; Fabius, A.W.M.; Baia, G.S.; Eberhart, C.G.; Weingart, J.D.; Gallia, G.L.; Baylin, S.B.; Chan, T.A.; et al. 5-azacytidine reduces methylation, promotes differentiation and induces tumor regression in a patient-derived IDH1 mutant glioma xenograft. Oncotarget 2013, 4, 1737-1747. [CrossRef] [PubMed]

122. Turcan, Ş.; Fabius, A.W.M.; Borodovsky, A.; Pedraza, A.; Brennan, C.W.; Huse, J.; Viale, A.; Riggins, G.J.; Chan, T.A. Efficient induction of differentiation and growth inhibition in IDH1 mutant glioma cells by the DNMT Inhibitor Decitabine. Oncotarget 2013, 4, 1729-1736. [CrossRef] [PubMed]

123. Fathi, A.T.; Abdel-Wahab, O. Mutations in Epigenetic Modifiers in Myeloid Malignancies and the Prospect of Novel Epigenetic-Targeted Therapy. Adv. Hematol. 2012, 2012, 1-12. [CrossRef] [PubMed]

124. Gursoy-Yuzugullu, O.; Carman, C.; Serafim, R.B.; Myronakis, M.; Valente, V.; Price, B.D. Epigenetic therapy with inhibitors of histone methylation suppresses DNA damage signaling and increases glioma cell radiosensitivity. Oncotarget 2017, 8, 24518-24532. [CrossRef] [PubMed]

125. Bent, M.J.V.D.; Mellinghoff, I.K.; Bindra, R.S.; Binja, R. Gray Areas in the Gray Matter: IDH1/2 Mutations in Glioma. Am. Soc. Clin. Oncol. Educ. Book 2020, 40, 96-103. [CrossRef]

126. Esteller, M.; García-Foncillas, J.; Andion, E.; Goodman, S.N.; Hidalgo, O.F.; Vanaclocha, V.; Baylin, S.B.; Herman, J.G. Inactivation of the DNA-Repair GeneMGMTand the Clinical Response of Gliomas to Alkylating Agents. N. Engl. J. Med. 2000, 343, 1350-1354. [CrossRef]

127. Hegi, M.; Diserens, A.-C.; Gorlia, T.; Hamou, M.-F.; De Tribolet, N.; Weller, M.; Kros, J.M.; Hainfellner, J.A.; Mason, W.; Mariani, L.; et al. MGMTGene Silencing and Benefit from Temozolomide in Glioblastoma. N. Engl. J. Med. 2005, 352, 997-1003. [CrossRef]

128. Cai, S.J.; Liu, Y.; Han, S.; Yang, C. Brusatol, an NRF2 inhibitor for future cancer therapeutic. Cell Biosci. 2019, 9, 45. [CrossRef]

129. Emadi, A.; Jun, S.A.; Tsukamoto, T.; Fathi, A.T.; Minden, M.D.; Dang, C.V. Inhibition of glutaminase selectively suppresses the growth of primary acute myeloid leukemia cells with IDH mutations. Exp. Hematol. 2014, 42, 247-251. [CrossRef]

130. Matre, P.; Velez, J.; Jácamo, R.; Qi, Y.; Su, X.; Cai, T.; Chan, S.M.; Lodi, A.; Sweeney, S.R.; Ma, H.; et al. Inhibiting glutaminase in acute myeloid leukemia: Metabolic dependency of selected AML subtypes. Oncotarget 2016, 7, 79722-79735. [CrossRef]

131. Tateishi, K.; Wakimoto, H.; Iafrate, A.J.; Tanaka, S.; Loebel, F.; Lelic, N.; Wiederschain, D.; Bedel, O.; Deng, G.; Zhang, B.; et al. Extreme Vulnerability of IDH1 Mutant Cancers to NAD+ Depletion. Cancer Cell 2015, 28, 773-784. [CrossRef] [PubMed]

132. Tateishi, K.; Higuchi, F.; Miller, J.J.; Koerner, M.V.; Lelic, N.; Shankar, G.M.; Tanaka, S.; Fisher, D.E.; Batchelor, T.T.; Iafrate, A.J.; et al. The Alkylating Chemotherapeutic Temozolomide Induces Metabolic Stress in IDH1-Mutant Cancers and Potentiates NAD+ Depletion-Mediated Cytotoxicity. Cancer Res. 2017, 77, 4102-4115. [CrossRef] [PubMed]

133. Bunse, L.; Pusch, S.; Bunse, T.; Sahm, F.; Sanghvi, K.; Friedrich, M.; AlAnsary, D.; Sonner, J.K.; Green, E.; Deumelandt, K.; et al. Suppression of antitumor T cell immunity by the oncometabolite (R)-2-hydroxyglutarate. Nat. Med. 2018, 24, 1192-1203. [CrossRef] [PubMed]

134. Kohanbash, G.; Carrera, D.A.; Shrivastav, S.; Ahn, B.J.; Jahan, N.; Mazor, T.; Chheda, Z.S.; Downey, K.M.; Watchmaker, P.B.; Beppler, C.; et al. Isocitrate dehydrogenase mutations suppress STAT1 and CD8+ T cell accumulation in gliomas. J. Clin. Investig. 2017, 127, 1425-1437. [CrossRef] [PubMed]

135. Schumacher, T.; Bunse, L.; Pusch, S.; Sahm, F.; Wiestler, B.; Quandt, J.; Menn, O.; Osswald, M.; Oezen, I.; Ott, M.; et al. A vaccine targeting mutant IDH1 induces antitumour immunity. Nature 2014, 512, 324-327. [CrossRef] [PubMed]

136. Curry, W.T.; Lim, M. Immunomodulation: Checkpoint blockade etc.: Figure 1. Neuro-Oncology 2015, 17, vii26-vii31. [CrossRef] 
137. Weller, M.; Butowski, N.; Tran, D.D.; Recht, L.D.; Lim, M.; Hirte, H.; Ashby, L.; Mechtler, L.; A Goldlust, S.; Iwamoto, F.; et al. Rindopepimut with temozolomide for patients with newly diagnosed, EGFRvIII-expressing glioblastoma (ACT IV): A randomised, double-blind, international phase 3 trial. Lancet Oncol. 2017, 18, 1373-1385. [CrossRef]

138. Weller, M.; Roth, P.; Preusser, M.; Wick, W.; Reardon, D.A.; Platten, M.; Sampson, J.H. Vaccine-based immunotherapeutic approaches to gliomas and beyond. Nat. Rev. Neurol. 2017, 13, 363-374. [CrossRef]

139. Fecci, P.E.; Sampson, J.H. The current state of immunotherapy for gliomas: An eye toward the future. J. Neurosurg. 2019, 131, 657-666. [CrossRef]

140. Elhammali, A.; Ippolito, J.E.; Collins, L.; Crowley, J.; Marasa, J.; Piwnica-Worms, D.R. A high-throughput fluorimetric assay for 2-hydroxyglutarate identifies Zaprinast as a glutaminase inhibitor. Cancer Discov. 2014, 4, 828-839. [CrossRef]

141. Sulkowski, P.L.; Sundaram, R.K.; Oeck, S.; Corso, C.D.; Liu, Y.; Noorbakhsh, S.; Niger, M.; Boeke, M.; Ueno, D.; Kalathil, A.N.; et al. Krebs-cycle-deficient hereditary cancer syndromes are defined by defects in homologous-recombination DNA repair. Nat. Genet. 2018, 50, 1086-1092. [CrossRef] [PubMed]

142. Johannessen, T.-C.A.; Mukherjee, J.; Viswanath, P.; Ohba, S.; Ronen, S.M.; Bjerkvig, R.; Pieper, R.O. Rapid Conversion of Mutant IDH1 from Driver to Passenger in a Model of Human Gliomagenesis. Mol. Cancer Res. 2016, 14, 976-983. [CrossRef]

143. Molenaar, R.J.; Botman, D.; Smits, M.A.; Hira, V.V.; Van Lith, S.A.; Stap, J.; Henneman, P.; Khurshed, M.; Lenting, K.; Mul, A.N.; et al. Radioprotection of IDH1-Mutated Cancer Cells by the IDH1-Mutant Inhibitor AGI-5198. Cancer Res. 2015, 75, 4790-4802. [CrossRef] [PubMed]

144. Pusch, S.; Krausert, S.; Fischer, V.; Balss, J.; Ott, M.; Schrimpf, D.; Capper, D.; Sahm, F.; Eisel, J.; Beck, A.-C.; et al. Pan-mutant IDH1 inhibitor BAY 1436032 for effective treatment of IDH1 mutant astrocytoma in vivo. Acta Neuropathol. 2017, 133, 629-644. [CrossRef] [PubMed]

145. Chaturvedi, A.; Herbst, L.; Pusch, S.; Klett, L.; Goparaju, R.; Stichel, D.; Kaulfuss, S.; Panknin, O.; Zimmermann, K.; Toschi, L.; et al. Pan-mutant-IDH1 inhibitor BAY1436032 is highly effective against human IDH1 mutant acute myeloid leukemia in vivo. Leukemia 2017, 31, 2020-2028. [CrossRef]

146. Noorani, I. Genetically Engineered Mouse Models of Gliomas: Technological Developments for Translational Discoveries. Cancers 2019, 11, 1335. [CrossRef]

(C) 2020 by the authors. Licensee MDPI, Basel, Switzerland. This article is an open access article distributed under the terms and conditions of the Creative Commons Attribution (CC BY) license (http://creativecommons.org/licenses/by/4.0/). 